\title{
Aktifitas Antifungi Kitosan Hasil Hidrolisis Enzimatik Terhadap Penyakit Antraknosa
}

\author{
Yadi Suryadi $^{* 1}$, Dwiningsih Susilowati ${ }^{2}$, dan I Made Samudra ${ }^{3}$ \\ *e-mail penulis koresponden: yshid@yahoo.co.uk \\ ${ }^{1,2,3}$ Lab. Mikrobiologi dan Biokimia, BB Biogen, Jl Tentara Pelajar 3A, Bogor 16111
}

\begin{abstract}
Anthracnose disease caused by Colletotrichum gloeosporioides is one of an important fungal pathogen on mango fruits during the pre harvest or post harvest stage. The use of chitosan as an alternative method to control the disease is necessary due to its biodegradable, biocompatible and non-toxic effect. Chitosan tripolyphosphate (CTPP) showed higher inhibition to C. gloeosporioides compared with that of low molecular weight (LMW) chitosan as affected by its particle size. The best of disease inhibitory activity was revealed by C-TPP B [0.2\% LMW : $0.1 \%$ TPP; $(5: 2)]$ and C [0.2\% LMW: 0:08\% TPP; (5: 1)] treatments based on in vitro and in vivo test. Because of the concentration of chitosan and TPP may affect to particle structure, hence the C-TPP formation needs further to be optimized so that the size is getting smaller and stable.
\end{abstract}

Keywords: anthracnose, chitosan, C.gloeosporioides, chitinase

\begin{abstract}
ABSTRAK
Penyakit antraknosa yang disebabkan oleh Colletotrichum gloeosporioides adalah salah satu fungi patogen penting pada buah mangga selama tahap pra panen atau pasca panen. Penggunaan kitosan sebagai metode alternatif untuk mengendalikan penyakit diperlukan karena efeknya yang dapat terbiodegradasi, biokompatibel, dan tidak beracun. Kitosan tripolifosfat (K-TPP) menunjukkan penghambatan lebih tinggi terhadap C. gloeosporioides dibandingkan dengan kitosan dengan berat molekul rendah (BMR) karena dipengaruhi oleh ukuran partikelnya. Aktivitas penghambatan penyakit terbaik ditunjukkan oleh perlakuan K-TPP B [0,2\% LMW: 0,1\% TPP; (5: 2)] dan C [0,2\% LMW: 0: 08\% TPP; (5: 1)] berdasarkan uji in vitro dan in vivo. Karena konsentrasi kitosan dan TPP sangat berpengaruh terhadap struktur partikel, maka pembentukan K-TPP perlu dioptimalkan lebih lanjut sehingga ukurannya semakin kecil dan stabil.
\end{abstract}

Kata kunci: antraknosa, kitosan, C. gloeosporioides, kitinase

\section{PENDAHULUAN}

Salah satu kendala yang dihadapi oleh eksportir buah mangga adalah buah banyak mengalami kerusakan di penyimpanan. Buah mangga hanya dapat bertahan hingga 7 hari pada suhu ruangan, selebihnya mangga akan mengalami kerusakan selama proses pematangan fisiologis buah. Kerusakan buah mangga akibat fungi penyebab penyakit yang paling utama diantaranya adalah serangan antraknosa yang disebabkan fungi Colletotrichum gloeosporioides (Hu et al., 2014).

Pengendalian antraknosa pada buah pascapanen biasa dilakukan dengan pemberian fungisida sintetik seperti 
copper hydroxide, mancozeb, copper sulfate, prokloraz dan azoxystrobin (strobilurinbenomil) atau dikombinasikan dengan perlakuan-perlakuan lainnya (Sharma \& Kulshrestha, 2018). Namun, fungisida tersebut selain bersifat toksik dan mencemari lingkungan, juga bersifat resisten terhadap patogen dan membahayakan kesehatan manusia, oleh karena itu diperlukan alternatif pengendalian yang lebih aman.

Kitosan merupakan salah satu alternatif pengendalian antraknosa yang aman bagi manusia untuk karena bersifat biodegradabel, biokompatibel, dan nontoksik (Ing et al., 2012). Kitosan [(1,4)2-amino-2-deoksi-D-glukan] merupakan polisakarida berasal dari limbah kulit/cangkang Crustaeceae. Senyawa ini merupakan biopolimer alami yang bersifat polikationik sebagai hasil dari deasetilasi kitin (Ali et al., 2013). Karena sifat polikationik tersebut kitosan dapat dimanfaatkan sebagai antibakteri dan antifungi. Kitosan antara lain memiliki aktifitas antifungi terhadap Aspergillus niger, Alternaria alternata (Zhong et al., 2007) dan Rhizopus stolonifer (Lauzardo et al., 2009). Aktivitas kitosan terhadap fungi $C$. gloeosporioides setelah diteliti secara in vivo terhadap buah naga (Ali et al., 2013) dan pepaya (Hewajulige et al., 2009) dan terbukti dapat menghambat pertumbuhan fungi tersebut.

Hasil penelitian menunjukkan bahwa aktivitas antifungi kitosan dipengaruhi oleh bobot molekul (BM), derajat substitusi, konsentrasi, jenis fungi, dan tipe gugus fungsi pada rantai turunannya. Kitosan dapat dipreparasi menjadi kitosan bobot molekul rendah (K-BMR) hingga berukuran nanopartikel. Semakin kecil ukurannya maka aktivitas kitosan akan mengalami kenaikan (Ali et al., 2013). Preparasi K-BMR dapat dilakukan dengan bantuan enzim hasil metabolit sekunder bakteri Bacillus firmus (E-65). Isolat tersebut diketahui memiliki aktivitas kitinase yang tinggi dalam mendegradasi kitin (Suryadi et al., 2013) sehingga dapat dimanfaatkan untuk mendegradasi kitosan menjadi K-BMR (Mulyaningtyas et al., 2016). Degradasi molekul secara enzimatik mempunyai beberapa kelebihan, yaitu lebih ramah lingkungan, lebih spesifik terhadap substrat tertentu, dan K-BMR yang dihasilkan lebih baik strukturnya.

Molekul dengan ukuran partikel mikro dan atau nano akan terbentuk secara spontan apabila ke dalam larutan kitosan dengan konsentrasi tertentu ditambahkan dengan larutan polianion seperti tripolifosfat yang disertai dengan pengadukan terus menerus. Ukuran partikel kitosan yang terbentuk ditentukan antara lain oleh perbandingan konsentrasi kitosan dengan TPP (Ing et al., 2012).

Penelitian ini bertujuan mendapatkan kondisi optimum preparasi partikel kitosan dengan karakteristik terbaik untuk mengendalikan penyakit antaknosa pada mangga melalui pengujian in vivo dan in vitro.

\section{BAHAN DAN METODE}

\section{Preparasi bakteri dan pengujian aktivitas kitinase secara kuantitatif \\ Isolat bakteri Bacillus firmus E65} (BiogenCC) dibiakkan pada media Luria Bertani (LB) cair selama 18 jam. Kemudian $1 \mathrm{~mL}$ media $\mathrm{LB}$ cair yang berisi biakan bakteri diinokulasikan ke dalam media kitin cair. Biakan diinkubasi selama 7 hari pada suhu ruangan sambil digoyang dengan putaran $75 \mathrm{rpm}$ menggunakan orbital shaker (IKA K260). Media kitin cair yang berisi biakan bakteri disentrifugasi dengan kecepatan $10.000 \mathrm{rpm}$ (Hettich D-78532) selama 20 menit pada suhu $4^{\circ} \mathrm{C}$. Supernatan merupakan ekstrak kasar enzim. Presipitasi enzim dilakukan dengan mencampurkan amonium sulfat $70 \% \mathrm{ke}$ dalam supernatan dengan volume yang sama sambil diaduk pada suhu $>10^{\circ} \mathrm{C}$. 
Selanjutnya campuran tersebut disentrifugasi lagi dengan kecepatan $10.000 \mathrm{rpm}$ selama 30 menit pada suhu $4^{\circ} \mathrm{C}$. Pelet enzim kemudian dilarutkan dalam PBS pH 6.8 dalam jumlah yang minimal. Enzim tersebut selanjutnya disimpan dalam freezer sebelum digunakan.

Aktivitas kitinase dari enzim kitinolitik asal Bacillus firmus E65 diuji secara kuantitatif dengan mengukur konsentrasi N-asetil-D-glukosamin (GlcNAc) yang terbentuk mengacu prosedur (Toharisman et al., 2015). Pengukuran absorbansi sampel dilakukan dengan mencampurkan $450 \mu \mathrm{L}$ enzim, $450 \mu \mathrm{L}$ PBS pH 7, dan $900 \mu \mathrm{L}$ koloid kitin kemudian dikocok dengan vortex dan diinkubasi pada suhu $37^{\circ} \mathrm{C}$ selama 30 menit pada inkubator (Memmert INE500). Campuran tersebut disentrifugasi dengan kecepatan 5000 rpm selama 5 menit. Supernatan yang telah diperoleh diambil sebanyak $500 \mu \mathrm{L}$ kemudian ditambahkan dengan $500 \mu \mathrm{L}$ akuades dan $1 \mathrm{~mL}$ pereaksi Schales, campuran didihkan pada $100^{\circ} \mathrm{C}$ selama 10 menit. Setelah didinginkan, sampel diukur dengan spektrofotometer (Hitachi) pada absorbansi $\lambda_{420 \mathrm{~nm}}$.

Pembuatan K-BMR, dan preparasi kitosan tripolifosfat (K-TPP) metode gelasi ionik

Pembuatan K-BMR mengacu pada penelitian (Kumar et al., 2007). Masing-masing sebanyak $2 \mathrm{~g}, 0.25 \mathrm{~g}, 0.5$ g, $1.0 \mathrm{~g}$, dan $1.25 \mathrm{~g}$ kitosan (derajat deasetilasi 93.8\%), dilarutkan dalam 100 $\mathrm{mL}$ larutan asam asetat $1 \%, \mathrm{pH} 3.5$. Campuran tersebut diaduk selama 24 jam menggunakan pengaduk magnetik agar kitosan larut. Larutan kitosan yang telah larut disaring dan diatur $\mathrm{pH}$-nya menjadi 5.3 dengan ditambahkan $\mathrm{NaOH}$. Larutan kitosan sebanyak $20 \mathrm{~mL}$ dihidrolisis menggunakan $0.2 \mathrm{~mL}$ kitinase pada suhu $37^{\circ} \mathrm{C}$ serta waktu inkubasi selama 2 jam. Proses hidrolisis dihentikan dengan pemanasan $100^{\circ} \mathrm{C}$ selama 5 menit. Hidrolisat selanjutnya dipresipitasi dengan sentrifugasi $10.000 \mathrm{rpm}$ selama 10 menit, peletnya dicuci beberapa kali dengan air destilasi hingga $\mathrm{pH}$ netral. Pelet tersebut merupakan K-BMR. Pelet hasil presipitasi disimpan dalam lemari pendingin sampai dilakukan pengujian selanjutnya.

K-TPP dipreparasi dengan memodifikasi metode (Mardliyati et al., 2012). K-BMR dilarutkan dalam asam asetat $1 \%$ sehingga konsentrasinya menjadi $0.1 \%$ dan $0.2 \%$, kemudian diaduk menggunakan pengaduk magnet pada kecepatan sedang. Larutan ditambahkan $0.25 \mathrm{~mL}$ tween $80 \quad 0.2 \%$ setes demi setetes dengan tetap diaduk selama 30 menit. Sementara itu, larutan TPP $0.1 \%$ dan $0.08 \%$ dibuat dengan melarutkan TPP ke dalam air deionisasi. Larutan TPP pada berbagai variasi rasio volume ditambahkan setetes demi setetes sambil tetap diaduk pada suhu ruang. Perbandingan volume (v/v) antara larutan K-BMR:TPP adalah (5:1) dan (5:2). Pengadukan terus dilanjutkan sampai satu jam agar proses ikat silang antara NaTPP dan K-BMR berlangsung sempurna. Suspensi partikel yang terbentuk kemudian disimpan dalam lemari es hingga dilakukan pengujian.

\section{Analisis struktur K-BMR dan K-TPP}

Sebanyak $2 \mathrm{mg}$ serbuk contoh dicampur dengan $100 \mathrm{mg} \mathrm{KBr}$ untuk dijadikan pelet. Pelet dibuat menggunakan handPress Shimadzu dengan tekanan 8 psi selama 15 menit. Spektrum diukur dengan spektrofotometer FTIR pada kisaran bilangan gelombang 4000 sampai 400 $\mathrm{cm}^{-1}$ (FTIR Tensor 37, Bruker). Ukuran partikel K-TPP diukur menggunakan PSA (Particle Size Analyzer) (Zetasizer Malvern, UK).

\section{Pengujian daya hambat terhadap fungi secara in vitro dan in vivo}


Metode tuang secara in vitro yang digunakan pada uji daya hambat nanokitosan terhadap fungi merupakan modifikasi metode ( Palma-Guerrero et al., 2008). Sebanyak $1 \mathrm{~mL}$ larutan kitosan pada berbagai variasi rasio ditambahkan ke media PDA yang masih hangat dalam cawan petri, kemudian dibiarkan mengeras. Media PDA dalam cawan petri berdiameter $9 \mathrm{~cm}$, pada bagian tengahnya dilubangi dengan alat cork borrer. Kemudian isolat C. gloesporioides diletakan ke lubang tersebut dan diikubasi selama 4 hari. Perlakuan kontrol hanya berisi PDA dan $C$. gloesporioides.

Metode pengujian in vivo dilakukan dengan memodifikasi metode (Gonzalez-Aguilar et al., 2008). Buah yang digunakan adalah mangga jenis Indramayu dengan ukuran yang seragam, kemudian dicuci bersih dengan air steril dan dikeringanginkan. Buah mangga kemudian direndam dalam larutan K-TPP dan dikeringanginkan. Selanjutnya buah ditusuk-tusuk dengan jarum steril dan diimersi dengan suspensi konidia $C$. gloeosporioides $\left(10^{7}\right.$ konidia $\left./ \mathrm{mL}\right)$ dan dikeringanginkan. Perlakuan kontrol dilakukan dengan cara sama tetapi nanokitosan diganti akuades steril. Semua perlakuan dilakukan duplo. Buah disimpan di atas baki steril dan ditutup dengan plastik bening untuk menjaga kelembapan. Pengamatan keparahan penyakit pada perlakuan buah mangga dilakukan setelah 4 hari. Skor keparahan penyakit antraknosa dinilai berdasarkan skala $0-5$ sebagai berikut: skor $0=$ $0 \leq x<1 \% ; 1=1 \leq x \leq 20 \% ; 2=21 \leq x \leq 40$ $\% ; 3=41 \leq x \leq 60 \% ; 4=61 \leq x \leq 80 \%$; dan $5=81 \leq x \leq 100 \%$ buah tertutupi oleh patogen.

Daya hambat (DH) terhadap patogen fungi dihitung dengan rumus sebagai berikut:

$\mathrm{DH}=\frac{(\mathrm{Ik}-\mathrm{IP})}{\mathrm{Ik}} \times 100 \%$ dimana $\mathrm{Ik}=$ intensitas penyakit pada kontrol; Is= intensitas penyakit pada perlakuan (Suryadi et al., 2017).

\section{HASIL DAN PEMBAHASAN}

\section{Aktivitas kitinase secara kuantitatif}

Hasil pengukuran aktivitas enzim asal bakteri isolat E65 menunjukkan konsentrasi NAcGlc sebesar $24.331 \pm$ $1.840 \quad(\mathrm{mg} / \mathrm{mL})$. Perolehan aktivitas enzim ini sudah cukup untuk digunakan dalam menghidrolisis kitosan lebih lanjut menjadi kitosan dengan BM lebih rendah.

\section{Analisis Struktur K-BMR dan K-TPP}

Analisis FTIR dilakukan untuk menganalisa gugus fungsi yang ada pada K-BMR dan K-TPP. Spektrum FTIR dari K-BMR memiliki pita serapan yang khas dari gugus hidroksil, eter, dan amina primer yang terdapat pada strukturnya (Brugnerotto et al., 2001). Gambar 1 menunjukkan puncak-puncak spesifik pada K-BMR. Pada bilangan gelombang $3395 \mathrm{~cm}^{1}{ }^{1}$ terdapat pita serapan dari gugus $\mathrm{OH}$ dan pada $2924 \mathrm{~cm}^{-1}$ terdapat pita serapan dari $\mathrm{CH}$ alifatik. Pita serapan dari N-H tekuk pada amina primer ditunjukkan pada $1652 \mathrm{~cm}^{-1}$, selanjutnya pita serapan C-H tekuk terdapat pada $1443 \mathrm{~cm}^{-1}$. Gugus eter (C-O-C) ditunjukkan oleh puncak serapan pada $1068 \mathrm{~cm}^{-1}$.

Spektrum FTIR K-TPP memiliki perbedaan dengan spektrum K-BMR. Pada K-TTP bilangan gelombang 3434 $\mathrm{cm}^{-1}$ menunjukkan intensitas serapan gabungan dari gugus $\mathrm{NH}_{2}$ dan $\mathrm{OH}$ dari kitosan. Puncak serapan tersebut lebih tajam dibandingkan dengan puncak serapan dari K-BMR yang menunjukkan semakin banyaknya ikatan hidrogen yang terbentuk. Tambahan ikatan hidrogen berasal dari gugus hidroksil pada TPP sebagai hasil dari reaksi crosslinking (ikat silang) antara kitosan dan TPP. Ikatan $\mathrm{CH}$ ditunjukkan oleh intensitas serapan pada $2921 \mathrm{~cm}^{-1}$ (CH simetris) dan 2852 
$\mathrm{cm}^{-1} \quad(\mathrm{CH}$ asimetris$)$. Pada bilangan gelombang $1630 \mathrm{~cm}^{-1}$ puncak serapan $\mathrm{N}$ $\mathrm{H}$ pada K-TPP lebih tajam dibandingkan dengan K-BMR yang menunjukkan derajat deasetilasi K-TPP lebih tinggi dibandingkan dengan K-BMR. Adanya

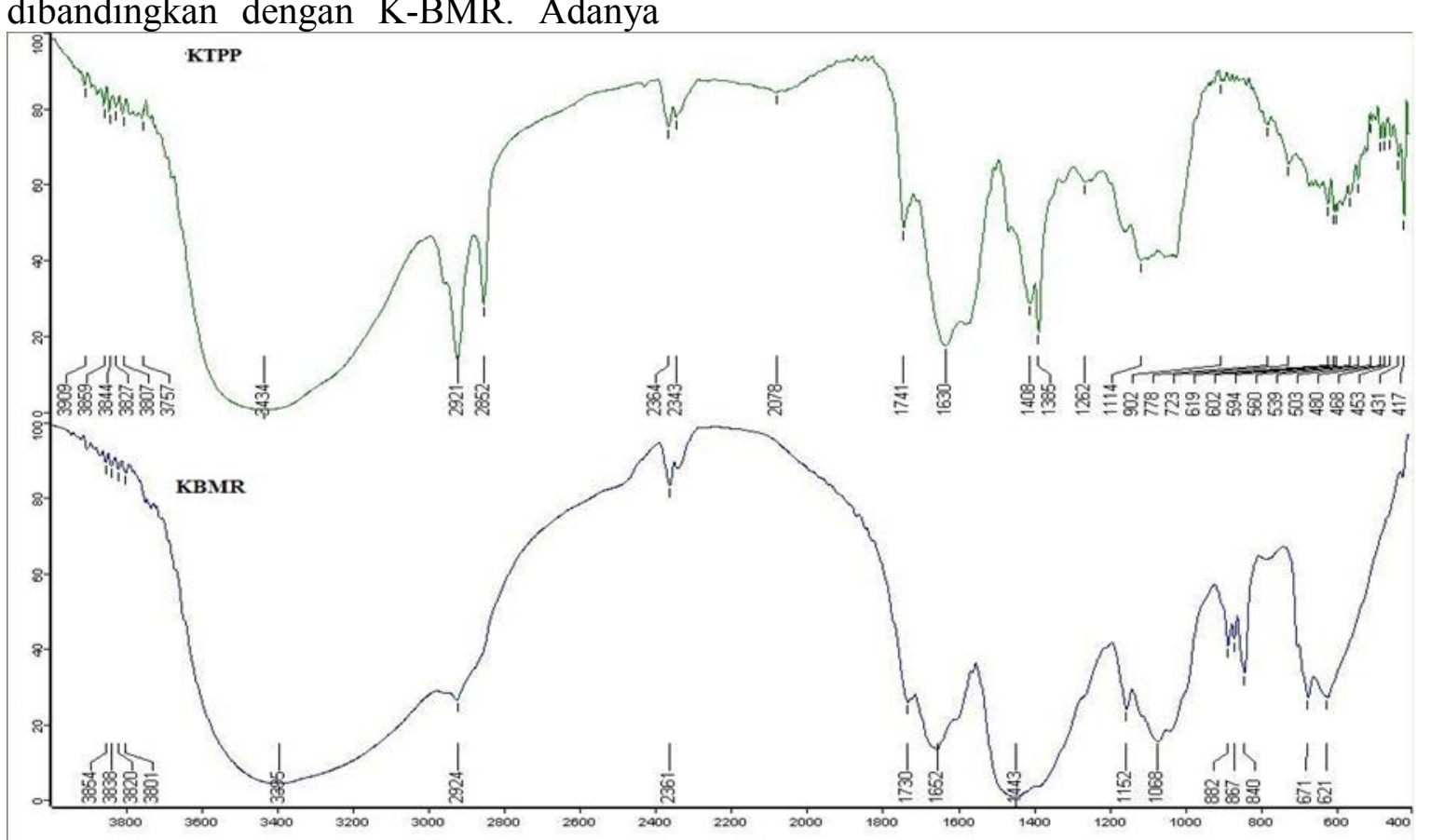

\section{Gambar 1. Spektrum FTIR dari K-BMR dan K-TPP}

\section{Uji Penghambatan in vitro}

Hasil uji penghambatan secara in vitro menunjukkan bahwa K-TPP dan $\mathrm{K}$ BMR mampu menghambat pertumbuhan fungi C. gloeosporioides masing-masing dengan kisaran penghambatan 20.99 $95.06 \%$ dan 7.07 - 28.26\%. Kitosan dapat menghambat pertumbuhan konidia, buluh kecambah, kelebatan hifa, panjang dan lebar hifa, serta melisis hifa pada fungi (Lauzardo et al., 2009).

Aktivitas antifungi salah satunya dipengaruhi oleh konsentrasi kitosan. Pada konsentrasi K-BMR yang lebih rendah aktifitas antifungi cenderung mengalami penurunan yang ditunjukkan dengan nilai DH yang semakin menurun. Hal tersebut kemungkinan disebabkan oleh konsentrasi molekul-molekul kitosan yang terlarut relatif rendah sehingga belum mampu untuk menghambat pertumbuhan fungi dengan sempurna. proses ikat silang antara TPP dan kitosan ditunjukkan dengan pita serapan baru dari K-TPP pada bilangan gelombang 1262 $\mathrm{cm}^{-1}$ yang berasal dari gugus $\mathrm{P}=\mathrm{O}$. 
BMR. Aktifitas tertinggi diperoleh pada perlakuan K-TPP B dan K-TPP C dengan daya penghambatan masing-masing sebesar 95.06\%. Aktifitas terendah ditunjukkan perlakuan K-TPP A, K-TPP $\mathrm{D}$, dan K-TPP $\mathrm{G}$ dengan nilai $\mathrm{DH}$ masing-masing sebesar $20.99 \%$ (Tabel 1). Rendahnya aktifitas antifungi pada tiga perlakuan tersebut kemungkinan diakibatkan rendahnya interaksi antara kitosan dengan permukaan sel fungi akibat terhalang oleh molekul TPP sebagai hasil proses ikat silang yang belum sempurna. Disamping itu distribusi molekul kitosan yang mungkin tidak merata pada media juga menjadi penyebab rendahnya aktivitas penghambatan kitosan. Hal tersebut dibuktikan pada ketiga perlakuan tersebut terdapat sisi-sisi yang tidak ditumbuhi oleh fungi, walaupun ruang di sekitarnya sudah dipenuhi oleh hifa dari fungi tersebut (Gambar 2).

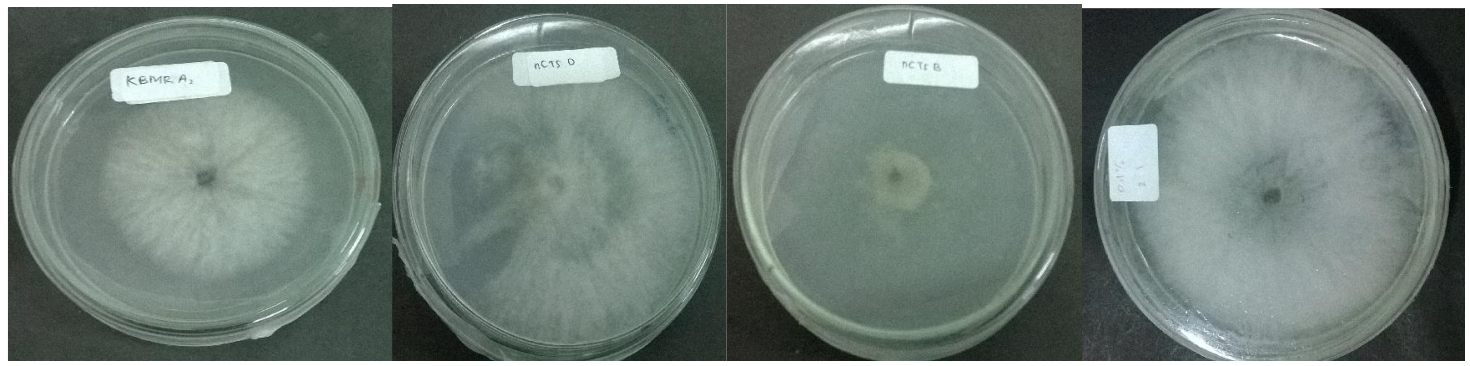

(a) (b) (c)

(d)

Gambar 2. Contoh daya hambat secara in vitro, K-BMR A (a), K-TPP D (b), K-TPP B (c), kontrol (d)

Tabel 1. Uji daya hambat (DH) KTTP dan K-BMR secara in vitro

\begin{tabular}{llllll}
\hline Perlakuan & $\begin{array}{l}{[\mathrm{K}-} \\
\mathrm{BMR}] \\
(\%)\end{array}$ & $\begin{array}{l}{[\mathrm{TPP}]} \\
(\%)\end{array}$ & $\begin{array}{l}\text { Perbandingan } \\
\text { volume }(\mathrm{v} / \mathrm{v})\end{array}$ & $\begin{array}{l}\text { Luas koloni } \\
\text { fungi }\left(\mathrm{cm}^{2}\right)\end{array}$ & $\begin{array}{l}\mathrm{DH} \\
(\%)\end{array}$ \\
\hline Kontrol & - & - & - & 63.59 & 0.00 \\
K-TPP A & 0.2 & 0.1 & $5: 1$ & 50.24 & 20.99 \\
K-TPP B & 0.2 & 0.1 & $5: 2$ & 3.14 & 95.06 \\
K-TPP C & 0.2 & 0.08 & $5: 1$ & 3.14 & 95.06 \\
K-TPP D & 0.2 & 0.08 & $5: 2$ & 50.24 & 20.99 \\
K-TPP E & 0.1 & 0.1 & $5: 1$ & 19.63 & 69.14 \\
K-TPP F & 0.1 & 0.1 & $5: 2$ & 44.16 & 30.56 \\
K-TPP G & 0.1 & 0.08 & $5: 1$ & 50.24 & 20.99 \\
K-TPP H & 0.1 & 0.08 & $5: 2$ & 15.90 & 75.00 \\
K-BMR A & 0.25 & - & - & 28.26 & 55.56 \\
K-BMR B & 0.5 & - & - & 15.90 & 75.00 \\
K-BMR C & 1.0 & - & - & 7.07 & 88.89 \\
K-BMR D & 1.25 & - & - & 19.63 & 69.14 \\
\hline
\end{tabular}

Uji Penghambatan in vivo

Hasil uji in vivo pada buah mangga setelah 4 hari masa inkubasi menunjukkan bahwa K-TPP lebih efektif dalam menghambat pertumbuhan fungi. Hal tersebut diduga diakibatkan oleh ukuran dan berat molekul K-TPP yang lebih kecil. Adanya proses ikat silang 
antara kitosan dengan TPP menyebabkan struktur K-TPP menjadi kompak, padat, dan akhirnya membentuk struktur tiga dimensi yang berukuran nano atau mikro. Permukaan pada partikel ini kaya dengan muatan positif sehingga lebih efektif untuk berikatan dengan plasma membran sel yang bermuatan negatif (Jovanović et al., 2016). Muatan $\mathrm{NH}_{3}{ }^{+}$dari kitosan akan berkompetisi dengan ion $\mathrm{Ca}^{2+}$ dari membran sel sehingga stabilitas sel fungi menjadi terganggu (Goy et al.,2009). Hasil ini juga selaras dengan penelitian Ing et al., (2012), dimana dinyatakan aktifitas kitosan yang berukuran nano atau mikro akan mempunyai aktifitas antifungi yang lebih besar dibandingkan dalam bentuk polimernya. Selain itu dengan ukuran yang kecil, K-TPP lebih mudah berdifusi kedalam sel fungi untuk mengganggu aktifitas sintesis DNA dan RNA-nya (Ing et al., 2012).

Daya hambat K-TPP diharapkan dapat mempunyai aktifitas yang tinggi pada ukuran molekul yang lebih kecil. Ukuran molekul ini antara lain dipengaruhi oleh konsentrasi kitosan, TPP, dan rasio volume antar keduanya (Mardliyati et al., 2012) Konsentrasi kitosan yang besar akan memberikan daya hambat yang lebih besar. Hal ini terlihat pada K-TPP dengan konsentrasi $0.2 \%$ yang memiliki aktifitas penghambatan yang optimum dibandingkan dengan K-TPP dengan konsentrasi $0.1 \%$ (Tabel 2).

Tabel 2. Uji daya hambat K-TPP terhadap antraknosa pada buah mangga secara in vivo

\begin{tabular}{llllll}
\hline Perlakuan & $\begin{array}{l}{[\mathrm{K}-\mathrm{BMR}]} \\
(\%)\end{array}$ & $\begin{array}{l}{[\mathrm{TPP}]} \\
(\%)\end{array}$ & $\begin{array}{l}\text { Perbandingan } \\
\text { volume }(\mathrm{v} / \mathrm{v})\end{array}$ & $\begin{array}{l}\text { Rata-rata Intensitas } \\
\text { keparahan }(\%)\end{array}$ & DH (\%) \\
\hline Kontrol & - & - & - & 70,5 & 0,00 \\
K-TPP A & 0,2 & 0,1 & $5: 1$ & 20,5 & 70,92 \\
K-TPP B & 0,2 & 0,1 & $5: 2$ & 5,25 & 92,55 \\
K-TPP C & 0,2 & 0,08 & $5: 1$ & 5,25 & 92,55 \\
K-TPP D & 0,2 & 0,08 & $5: 2$ & 40,5 & 42,55 \\
K-TPP E & 0,1 & 0,1 & $5: 1$ & 20,5 & 70,92 \\
K-TPP F & 0,1 & 0,1 & $5: 2$ & 10,5 & 85,11 \\
K-TPP G & 0,1 & 0,08 & $5: 1$ & 20,5 & 70,92 \\
K-TPP H & 0,1 & 0,08 & $5: 2$ & 5,25 & 92,55 \\
\hline
\end{tabular}

Konsentrasi TPP
berpengaruh terhadap K-TPP
terbentuk, hasil menunjukkan bahwa
konsentrasi TPP yang lebih kecil
membuat K-TPP yang terbentuk
memiliki DH yang lebih besar. Hal ini
dapat terlihat pada K-TPP G dan H
memiliki rata-rata DH yang lebih besar
dibandingkan dengan rata-rata DH K-
TPP E dan F. Rasio volume antara
kitosan dan TPP juga berpengaruh,
kitosan dengan volume yang lebih besar
akan memberikan nilai DH yang lebih
besar. Akan tetapi, terlihat bahwa pada

rasio 5:2 memberikan rata-rata nilai $\mathrm{DH}$ yang hampir serupa dengan rasio 5:1. Hasil tersebut menunjukkan bahwa pada penelitian ini kedua rasio tersebut tidak terlalu berpengaruh pada daya hambat KTPP yang terbentuk.

K-TPP B dan C paling efektif dalam menghambat pertumbuhan fungi dengan nilai $\mathrm{DH}$ sebesar $92.55 \%$ (Tabel 2). Hasil analisa PSA (Particle Size Analyzer) menunjukkan bahwa rata-rata ukuran molekul B dan C sebesar 143,7 $\mathrm{nm}$ dan 142,1 nm. Walaupun demikian nilai indeks polidispersitas (IP) dari K- 
TPP B cukup rendah yaitu sebesar 0.488 , sedangkan untuk K-TPP C nilai IP masih kurang, yaitu 0.638. Nilai IP ini menunjukkan distribusi molekul dalam larutan, semakin tinggi nilai IP maka molekul-molekulnya semakin tidak seragam. Keseragaman molekul akan berpengaruh terhadap efektivitas penghambatan, umumnya semakin rendah nilai IP maka efektivitas penghambatannya semakin besar (Ing et al., 2012). Akan tetapi pada penelitian ini nilai IP tersebut tidak berpengaruh terhadap DH yang dihasilkan. Hasil penelitian uji PSA sebelumnya melaporkan bahwa perbandingan K-TPP (3:1) menunjukkan nilai rata-rata ukuran nano kitosan yaitu 228,74 nm (Mulyaningtyas et al., 2016).

\section{KESIMPULAN}

K-TPP menunjukkan aktifitas penghambatan terhadap $C$. gloeosporioides yang lebih besar dibandingkan dengan K-BMR. Aktifitas ini dipengaruhi oleh ukuran K-TPP yang lebih kecil dibandingkan dengan K-BMR.

Aktifitas penghambatan terbaik secara in vitro dan in vivo diperoleh dari perlakuan K-TPP B [0.2 \% K-BMR : $0.1 \%$ TPP; $(5: 2)]$ dan K-TPP C [0.2 \% KBMR : $0.08 \%$ TPP; (5:1)].

Hasil analisa PSA (Particle Size Analyzer) menunjukkan bahwa rata-rata ukuran molekul B dan C sebesar 143,7 nm dan $142.1 \mathrm{~nm}$.

Perlu dilakukan optimasi terhadap K-TPP agar ukuran yang terbentuk semakin kecil. Selain itu, analisis viskositas, bobot molekul, dan $\mathrm{pH}$ juga perlu dilakukan karena hal tersebut juga menentukan validasi terhadap struktur KTPP yang terbentuk.

\section{Ucapan Terima Kasih}

Penulis mengucapkan terima kasih kepada Sdr. Rosidah Rahman dan teknisi Lab. Nanoteknologi BB Pasca
Panen serta Biofarmaka IPB atas bantuan dalam analisis nanopartikel dan FTIR.

\section{DAFTAR PUSTAKA}

Ali, A., Zahid, N., Manickam, S., \& Siddiqui, Y. (2013). Effectiveness of submicron chitosan dispersions in controlling anthracnose and maintaining quality of dragon fruit. Postharvest Biology and Technology, 86, 147-153.

Brugnerotto, J., Lizardi, J., Goycoolea, F. M., Argüelles-Monal, W., Desbrières, J., \& Rinaudo, M. (2001). An infrared investigation in relation with chitin and chitosan characterization. Polymer, 42(8), 3569-3580.

https://doi.org/10.1016/S00323861(00)00713-8

Gonzalez-Aguilar, G. A., Celis, J., Sotelo-Mundo, R. R., De La Rosa, L. A., Rodrigo-Garcia, J., \& Alvarez-Parrilla, E. (2008). Physiological and biochemical changes of different fresh-cut mango cultivars stored at $5^{\circ} \mathrm{C}$. International Journal of Food Science and Technology, 43(1), 91101. https://doi.org/10.1111/j.13652621.2006.01394.x

Goy, R. C., Britto, D. De, \& Assis, O. B. G. (2009). A review of the antimicrobial activity of chitosan. Polimeros:Ciencia et Tecnologia. 19(3), 241247.https://doi.org/10.1590/S010414282009000300013

Hewajulige, I., Sultanbawa, Y., \& Wijeratnam, S. W. (2009). Mode of action of chitosan coating on anthracnose disease control in papaya. Phytoparasitica. 37, 437444.

https://doi.org/10.1007/s12600009-0052-5

Hu, M., Yang, D., Huber, D. J., Jiang, Y., Li, M., Gao, Z., \& Zhang, Z. (2014). Reduction of postharvest 
anthracnose and enhancement of disease resistance in ripening mango fruit by nitric oxide treatment. Postharvest Biology and Technology, 97, 115-122. https://doi.org/10.1016/j.postharvbi o.2014.06.013

Ing, L. Y., Zin, N. M., Sarwar, A., \& Katas, H. (2012). Antifungal activity of chitosan nanoparticles and correlation with their physical properties. International Journal of Biomaterials, 2012, 1-9. https://doi.org/10.1155/2012/63269 8

Palma-Guerrero J., Jansson H.B., Salinas, J., \& Liorca, L.V.L. (2008). Effect of chitosan on hyphal growth and spore germination of plant pathogenic and biocontrol fungi, $J$. of Applied Microbiology 104, 541-553. https://doi.org/10.1111/j.13652672. 2007.03567.x

Jovanović, G. D., Klaus, A. S., \& Nikšić, M. P. (2016). Antimicrobial activity of chitosan coatings and films against Listeria monocytogenes on black radish. Revista Argentina de Microbiología, 48(2), 128-136. https://doi.org/10.1016/j.ram.2016. 02.003

Kumar, A.B.V., Varadaraj, M.C., Gowda, L.R., \& Tharanathan, R,N. (2007). Low molecular weight chitosanpreparation with the aid of pronase, characterization and their bactericidal activity towards Bacillus cereus and Escherichia coli. Biochimica et Biophysica Acta. 1770: 495-505. (2007).

Lauzardo, A.N.H., Del Valle, M.G.V., Castelan, L.V., Giorgana, G.E.M, \& Sánchez, M.G.G. (2009). Effect of chitosan on three isolates of Rhizopus stolonifer obtained from peach, papaya and tomato, Fruits 65(4),

245-253. https://doi.org/10.1051/fruits/20100 20

Li, X.F., Feng, X.Q., Yang, S., Wang, T.P., \& Su, Z.X. (2008). Effects of molecular weight and concentration of chitosan on antifungal activity against Aspergillus niger. Iranian Polymer Journal, 17(11), 843-852.

Mardliyati, E., Sjaikhurrizal E.M, Damai R.S. 2012. Sintesis nanopartikel kitosan-trypoly phosphate dengan metode gelasi ionik: Pengaruh konsentrasi dan rasio volume terhadap karakteristik partikel. Prosiding Pertemuan Ilmiah Ilmu Pengetahuan dan Teknologi Bahan; 2012 (Okt 3); Serpong, Indonesia. Serpong (ID): BPPT. hlm 90-93.

Sharma, M \& Kulshrestha, S. (2018). Colletotrichum gloeosporioides: An anthracnose causing pathogen of fruits and vegetables, Biosciences Biotechnology Research Asia,12 (2),1-14. https://doi.org/10.13005/bbra/1776

Mulyaningtyas, D., A, Purwantisari, S., Kusdiyantini, E., \& Suryadi, Y. (2016). Produksi kitosan secara enzimatik oleh Bacillus firmus E65 untuk pengendalian penyakit antraknosa pada buah mangga (Mangifera Indica L.). Jurnal Biologi, 5(4), 8-17.

Suryadi, Y., Priyatno, T. P., Samudra, I. M., Susilowati, D. N., Patricia, \& Irawati, W. (2013). Karakterisasi dan identifikasi isolat bakteri endofitik penghambat jamur patogen Padi. Buletin Plasma Nutfah, 19(1), 25-32.

Suryadi, Y., Priyatno, T. P., Samudra, I. M., Susilowati, D., \& Sriharyani, T. S. (2017). Control of anthracnose disease ( Colletotrichum gloeosporioides) using nano chitosan hydrolyzed by chitinase derived from Burkholderia cepacia isolate E76, J. Agrobiogen 13(2), 111-122. 
Aktifitas Antifungi Kitosan......Yadi S., Dwiningsih S., dan I Made S......Sainmatika,...Volume 16,...No.2,...Desember $2019, \ldots 88-97$

Toharisman. (2015). Purification and characterization of a thermostable chitinase from Bacillus licheniformis Mb-2. World Journal of Microbiology and Biotechnology, 21, 733-738. https://doi.org/10.1007/s11274004-4797-1
Zhong, Z., Chen, R., Xing, R., Chen, X., Liu, S., Guo, Z., \& Li, P. (2007). Synthesis and antifungal properties of sulfanilamide derivatives of chitosan. Carbohydrate Research. 342 (16): 2390-2395. https://doi.org/10.1016/j.carres.200 7.07.015 